may make for difficulty and perhaps the work could be improved by better integration of the chapters.

This is not an adverse criticism of the book. It is merely a constructive criticism for the future, for there is no doubt that this work is the most useful book on operative obstetrics today in the English language. It is also the most beautifully produced and one of the most worth-while books on obstetrics in the whole of modern medical literature.

E.E.P.

\section{THE MANAGEMENT OF ABDOMINAL OPERATIONS}

\section{in two volumes}

Edited by Rodney Maingot, F.R.C.S. Second edition. Pp. xvi +1432 , with 640 illustrations. London: H. K. Lewis \& Co. Ltd. 1957. $£ 8$.

This is the second edition of an important surgical textbook. The first edition has been completely re-edited: and although the authors of most of the chapters are unchanged, they have brought their work as up to date as it is possible to do in the production of so large a book. The previous single cumbersome volume is replaced by two somewhat lighter ones, and the number of pages is increased by 126 . The index, which has been made even more complete, is to be found in both volumes. The whole is well put together, illustrations are simple and clear, and $\mathrm{x}$-ray pictures are carefully chosen and skilfully reproduced, with the single exception of fig. 175 which is printed upside down and shows a Bilroth I. gastrectomy emptying vertically upwards.

The object of the book is the complete presentation of all the practical aspects of abdominal surgery: and this object is more than fulfilled by the 32 contributors who have produced the 45 chapters. Naturally there is some repetition; but it is clear that the editor has taken great pains to make the book into a comprehensive whole, so that it is possible to read it through with a sustained interest and a clear sense of continuity. The book presupposes a reasonable knowledge of medicine and surgery, and one is spared the elementary considerations which introduce each chapter in so many other textbooks. The minute details of operative surgery are àlso omitted, whereas the type of operation to be done and the conditions which determine the choice are fully discussed. Thus the bookwhich will appeal most of all to postgraduates and fellowship candidates-is easily read and appreciated by the experienced surgeon, and forms a storehouse of information which would be otherwise available to him only in a large assortment of articles in a variety of journals.

Upwards of one-third of the book involves physiological considerations, and the chapters on fluid and electrolyte balance by L. P. le Quesne is especially recommended as being an outstanding example of the conciseness and clarity which characterises the whole work. A number of the chapters such as 'Preparation of the Good Risk
Patient,' 'The Role of Vitamins in Abdominal Surgery,' and ' Post-operative Parotitis,' while perhaps necessary for completeness, are unavoidably a little humdrum; and to my mind the most excellent chapter on anaesthesia by J. A. Lee will be of less interest to the general surgeon than the rest of the book. Nevertheless, in a work of this size there are bound to be some bleak spots, and these are more than compensated by the sustained interest of the remainder. General considerations occupy about one-third of the book, the remaining twothirds being devoted to regional problems. These chapters are well written, clearly illustrated and completely authoritative. Outstanding among them are those on gastric and duodenal ulcer and their complications by Mr. Maingot himself, and on the cardia and oesophagus by John Borrie. Over 300 pages are devoted to the stomach and duodenum and not a word is wasted. The little essay on infantile pyloric stenosis by David Levi is a model of clarity and common sense. Among the other chapters, the discussion of surgical aspects of pancreatic disease by E. G. Muir, and of the colon and rectum by $H$. R. Thompson are excellent, and the latter is especially well illustrated by diagrams and photographs.

Considered as a whole, the book is a very comprehensive survey of almost all possible problems associated with abdominal surgery. It is eminently readable, beautifully produced and, although expensive, is certainly worth the money.

\section{J.L.S.}

\section{THE DOCTOR, HIS PATIENT, AND THE ILLNESS}

By Michael Balint, M.D. Pp. $x+355$. London: Pitman Publishing Co. Ltd. 1957. 40s.

This is an exciting book about the oldest drug in the world. Considered by many to be, at best, a form of placebo, Dr. Balint successfully demonstrates it to be the most potent in our therapeutic armamentarium. And the drug? The doctor himself. This is an account of a long-term research project aimed at elucidating for practical purposes the very complex relationship which exists between the doctor and his patient. A team of 14 general practitioners and a psychiatrist met in a weekly seminar for several years to discuss their patients, their problems and themselves. The discussions were recorded verbatim and from this rich collection of data the author has edited in a very able manner the dominant theme which is basic to his main contention-that what the doctor does, and how he does it, is more important to the patient than all the E.C.ros and consultations.

It is now accepted that almost half of the patients who attend surgery possess psychological problems which have a direct bearing upon their complainteven at times upon the complaints of their spouse or their children! Unless these basic problems are tackled there can be little hope of effecting a complete and lasting cure at somatic level. In this book we read how these 14 doctors courageously pre- 
scribed themselves, with little advance knowledge of the dosage required, possible allergies, or the side-reactions that might be encountered. Their experiences will be familiar to every reader, although few will have dared to adopt their methods or have enjoyed their successes. Failures there have been, too, and it is a great credit to the members of this team that they have so honestly portrayed their weaknesses.

This book does not set out to sell psychosomatic medicine, nor to teach psychotherapy, but it does illustrate in a convincing manner that every medical practitioner possesses a considerable potential of therapeutic power which is seldom utilized, rarely recognized, and never mentioned by his mentors or textbook writers. It would be easy to sink into platitudes about this book; suffice it to say that here is a key to a' 'new look' in medicine, a book which should be read by consultants no less than the general practitioner, and most of all by the medical graduand looking at life with nosological orderliness.

L.R.C.H.

\section{CYTOLOGY OF THE BLOOD AND BLOOD- FORMING ORGANS}

By M. Bessis. Translated by E. Ponder. Pp. xxxii +629 , with 405 illustrations and 22 colour plates. New York and London: Grune and Stratton Inc. 1956. \$22.00.

Dr. Eric Ponder, who is a distinguished haematologist in his own right, has translated the 'Traité de Cytologie Sanguine' by Dr. Marcel Bessis, one of the finest cytologists of our time. The translation has attempted to retain the attractive, perhaps typically French style and with a few almost inevitable exceptions has succeeded very well indeed. Few people realize the difficulty of such a task, because idioms can so often elude translation, even in the hands of a bilingual translator.

The book itself is a real masterpiece, reflects Bessis's personality extremely well and conveys his profound understanding of his subject. It was, perhaps, a pity to group the coloured plates at the beginning. Their reproduction also has not been a happy one. About a quarter of the book is devoted to techniques and attention is paid to details. One wishes that the blood films sent for an opinion had been made by people who have realized the importance of Fig. 24. The second part deals with physiology and pathology of blood cells, providing a good survey. Surely the author should have used ' haemopoiesis ' instead of ' haematopoiesis.' The genitive has no place in this connection. The third and largest part is a study of the different series of blood cells. Red cells, granular cells, platelets and megakaryocytes, lymphocytes, histiocytes and others are very adequately described and the changes involving them discussed.

Most of the photographs are real masterpieces and almost all are useful. Although the book follows in its layout very strictly orthodox lines, one feels that the index should have deserved better treatment, but this is not the custom in France.

This is a book which will be treasured by many workers in the widening field of haematology and much can be learnt from it. Dr. Ponder has earned the gratitude of the English-speaking world for making accessible to those who do not understand French the work of Dr. Tzank's distinguished pupil. E.N.

\section{NERVES EXPLAINED}

By Richard Asher, M.D., F.R.C.P. Pp. 157. London: Faber and Faber. 1957. ros. 6d.

This is a pleasant if superficial little book addressed to the general public. In it the author explains what nervous disorders are in the neurological sense, then discourses briefly on psychoses and neuroses, and concludes with a rapid tour through such subjects as mental deficiency, geriatrics, Freud, sex, hypnosis, insomnia. tobacco addiction and hypochondria.

Some parts of the book suggest that the author is a little out of touch with mental health terminology; he is likely to be criticized for equating 'nervous breakdown' with psychosis and 'nervous upset' with neurosis in so arbitrary and dogmatic a manner, for example, and the statement that escaped criminal lunatics are usually mentally defective is questionable.

Nevertheless, this is a well-written and very readable book with much practical advice. It does much to dispose of the many wrong impressions about mental disorder still held by the layman and is likely to appeal to those for whom it has been written.

\section{A MANUAL OF ANAESTHETIC TECHNIQUES}

By W. J. Prior, M.B., Ch.B., F.F.A., D.A., M.F.A., R.A.C.S. Pp. viii + 224, with 77 illustrations. Bristol: John Wright \& Sons Ltd. 1956. 27s. $6 \mathrm{~d}$.

This manual sets out satisfactorily the various techniques of general anaesthesia in use to-day, but more detail and explanation would have been an advantage, especially as the book has been written primarily for the young anaesthetist.

Only three pages are devoted to pre-operative conditions requiring special care in anaesthesia. The advice given in this chapter is very sketchy and there is no mention of the common problem of the management of the patient requiring an emergency operation who is discovered to have diabetes.

There are also, unfortunately, several factual errors. For example, we are told that liquid nitrous oxide will escape if the cylinder is used while lying flat, and that Portex intratracheal tubes should not be boiled to sterilize although no alternative method! is: given. 